\title{
Organ-selective growth in the offspring of protein-restricted mothers
}

\author{
BY MINA DESAI ${ }^{1}$, NIGEL J. CROWTHER ${ }^{1}$, ALAN LUCAS ${ }^{2}$ \\ AND C. NICHOLAS HALES ${ }^{1 *}$ \\ ${ }^{1}$ Department of Clinical Biochemistry, University of Cambridge, Addenbrooke's Hospital, \\ Hills Road, Cambridge CB2 2QR \\ ${ }^{2}$ Dunn Nutritional Unit, University of Cambridge and Medical Research Council, Downham's Lane, \\ Milton Road, Cambridge CB4 IXJ
}

(Received 20 October 1995 - Revised 7 February 1996 - Accepted 16 February 1996)

\begin{abstract}
Recent epidemiological studies in people whose birth weights were recorded many years ago suggest links between impaired growth during early life and the development of diseases, including diabetes, much later in life. The long-term effects of retarded early growth are proposed to result from malnutrition at critical periods of fetal or infant development leading to reduction in the growth of organs and permanent changes in their metabolism or structure, or both. In order to investigate this, a rat model was established which involved feeding either a diet containing $200 \mathrm{~g}$ protein/ $/ \mathrm{gg}$ or an isoenergetic diet containing $80 \mathrm{~g}$ protein/ $\mathrm{kg}$ to pregnant and lactating rats. In addition, cross-fostering techniques were employed which allowed a separate evaluation of the prenatal or the postnatal periods. The offspring were studied at $21 \mathrm{~d}$ of age or were weaned onto a normal laboratory chow and studied at 11 months of age. The $80 \mathrm{~g}$ protein $/ \mathrm{kg}$ diet during pregnancy did not affect the overall reproductive performance although more subtle differences were evident. Permanent growth retardation was evident in offspring subjected to maternal protein restriction during the postnatal period. At $21 \mathrm{~d}$ of age the offspring of protein-restricted mothers exhibited selective changes in organ growth: compared with the body weight, the lung and brain experienced a smaller decrease in weight; the heart, kidney and thymus decreased proportionately; whereas, the pancreas, spleen, muscle and liver showed a greater reduction in weight. In older animals the muscle weight was lower in the male rats and the relative weight of pancreas was increased in the female rats.
\end{abstract}

Maternal diet: Growth: Nutritional programming

A series of epidemiological studies has shown an association between poor early human growth and development of hypertension, hypertriacylglycerolaemia, loss of glucose tolerance and insulin resistance in adult life (Barker et al. 1990, 1992, 1993; Hales et al. 1991 ; Hales \& Barker, 1992). The concept that early malnutrition can impair $\beta$-cell growth and function is consistent with early studies on malnourished children from the developing countries, in whom impaired glucose tolerance was found even after recovery from the nutritional insult (James \& Coore, 1970; Milner, 1971). Studies in experimental animals show clearly that these changes can be reproduced by subjecting either fetal or early postnatal animals to general protein-energy malnutrition (Weinkove et al. 1974) or, interestingly, to protein deficiency alone (Pimstone, 1976; Swenne et al. 1987). Recent studies have demonstrated that the protein supply to pregnant rats plays a key role in the development of the islets of Langerhans of the fetus. Also, diets containing a little under half the protein content of a diet fed to control rats led to the production of pups with

* For reprints. 
reduced neonatal $\beta$-cell proliferation, islet size and islet vascularization (Snoeck et al. 1990). These findings led to the hypothesis that an inadequate supply of amino acids to the fetus reduces growth and predisposes to the development of non-insulin-dependent diabetes in adult life (Hales \& Barker, 1992).

There are known to be critical periods during fetal development in which the establishment of tissues and organs is achieved. Growth failure at such times is to some extent irrecoverable. Some of the earliest work relating developmental physiology to nutrition and to outcome were the studies of McCance and Widdowson, and Winick and colleagues (Widdowson \& McCance, 1960, 1975; McCance \& Widdowson, 1966, 1974; Winick \& Noble, 1966; Winick et al. 1970; Widdowson, 1971; Winick, 1971). These studies together with subsequent studies collectively indicate that a reduced supply of nutrients during early life (prenatal and postnatal) interferes with the rate of cell multiplication in the various organs and that the effect is proportionally more deleterious in tissues with a faster rate of cell multiplication. The factor that determines whether the animal recovers appears to be the time at which malnutrition occurs. The earlier the undernutrition, the less likely is the recovery after the insult is discontinued. Animal studies provide further evidence for maternal nutritional influence passing from one generation to another. Marginal protein deficiency before mating and through gestation of the first generation of rats has been shown to lead to lower birth weights in the second generation. In addition, a proteindeficient rat colony maintained for over twelve generations showed a persistent reduction in maternal weight and newborn size. A remarkable finding was the fact that it required more than one generation to correct the reduction in fetal growth after re-institution of normal nutrition (Stewart et al. 1975).

The present study reports the effects on overall growth, including growth of specific organs, in the offspring as a result of maternal protein deprivation.

\section{EXPERIMENTAL METHODS \\ Animals and diet}

Virgin female Wistar rats of initial body weight $240-260 \mathrm{~g}$ from the Dunn Nutritional Laboratory were maintained at $22^{\circ}$ on a controlled $12 \mathrm{~h}$ light- $12 \mathrm{~h}$ dark cycle. They were mated with normal males and day 0 of gestation was taken as the day on which vaginal plugs were observed, after which they were housed individually. Thereafter, the rats were fed on either a diet containing $200 \mathrm{~g}$ protein $/ \mathrm{kg}$ or an isoenergetic diet containing $80 \mathrm{~g}$ protein $/ \mathrm{kg}$ throughout pregnancy and lactation. These diets were purchased from Hoppe Farms BV, Hoge Rijndijk 14, 3440 HD Woerden, The Netherlands and the composition is shown in Table 1.

The daily body weights and feed consumption of the pregnant rats on the two diets were monitored. Spontaneous delivery took place on day 22 of pregnancy after which, at $3 \mathrm{~d}$ of age, large litters were reduced to eight pups, thus ensuring a standard litter size per mother. The offspring were then followed in four groups.

\section{The offspring}

A total of twenty-four dams on the $200 \mathrm{~g}$ protein $/ \mathrm{kg}$ diet and twenty-four dams on the $80 \mathrm{~g}$ protein $/ \mathrm{kg}$ diet were studied. From this, half the dams $(n 12)$ from each diet group continued to nurse their offspring until $21 \mathrm{~d}$ of age. From the remaining dams ( $n 12$ per diet group) cross-fostering techniques were employed, such that the offspring of dams fed on the $200 \mathrm{~g}$ protein $/ \mathrm{kg}$ diet were nursed by dams fed on the $80 \mathrm{~g}$ protein $/ \mathrm{kg}$ diet, and vice versa. In order to do this, litters that were born on the same day were used. This allowed a separate evaluation of the effects of maternal protein restriction during gestation alone or 
Table 1. Composition of the $200 \mathrm{~g}$ protein $/ \mathrm{kg}$ and $80 \mathrm{~g}$ protein $/ \mathrm{kg}$ diets $(\mathrm{g} / \mathrm{kg})^{*}$

\begin{tabular}{lcc}
\hline \hline Diet... & 200 $\mathrm{g}$ protein $/ \mathrm{kg}$ & $80 \mathrm{~g}$ protein $/ \mathrm{kg}$ \\
\hline Mineral and vitamin mixture & 50.5 & 54.5 \\
Casein (880 g protein $/ \mathrm{kg})$ & 220.0 & 90.0 \\
DL-Methionine & 2.0 & 0.8 \\
Maize starch & 80.0 & 80.0 \\
Cellulose & 50.0 & 50.0 \\
Soyabean oil & 43.0 & 43.0 \\
Cerelose (glucose) & 551.5 & 681.7 \\
Energy (MJ/kg) & $15 \cdot 37$ & 15.28 \\
\hline
\end{tabular}

* The diets were purchased from Hoppe Farms BV, Hoge Rijndijk 14, 3440 HD Woerden, The Netherlands.

lactation alone in addition to maternal protein restriction carried out throughout gestation and lactation. Thus, the control group consisted of offspring of dams fed on a $200 \mathrm{~g}$ protein $/ \mathrm{kg}$ diet during pregnancy and nursed by dams on a $200 \mathrm{~g}$ protein $/ \mathrm{kg}$ diet. The low protein group consisted of offspring of dams fed on an $80 \mathrm{~g}$ protein $/ \mathrm{kg}$ diet over the same period of time. The postnatal low protein group consisted of offspring of dams fed on a $200 \mathrm{~g}$ protein $/ \mathrm{kg}$ diet during pregnancy who were subsequently nursed by dams on an $80 \mathrm{~g}$ protein $/ \mathrm{kg}$ diet. Finally, the prenatal low protein group was the reverse of the postnatal group, that is, they were the offspring of dams fed on an $80 \mathrm{~g}$ protein $/ \mathrm{kg}$ diet who were then nursed by dams on a $200 \mathrm{~g}$ protein $/ \mathrm{kg}$ diet. (This group has been referred to in previous papers as the 'recuperated' group.) It is emphasized that the dietary manipulation was carried out on pregnant and lactating rats only.

\section{Body weights}

Each litter from the four groups was weighed weekly, and the weight of an individual pup was calculated from it (i.e. litter weight/number of pups). The first weight was recorded at $3 \mathrm{~d}$ of age to avoid undue stress to the mothers and the pups. Subsequent weights were taken at 7, 14 and $21 \mathrm{~d}$ of age. At $21 \mathrm{~d}$ of age, males and females in each litter from the four groups were separated, after which, one or two pups of each sex were taken for organ studies. The remaining offspring were weaned onto a normal laboratory chow (LAD 1 diet, containing $200 \mathrm{~g}$ protein $/ \mathrm{kg}$; purchased from Special Diet Services, Witham, Essex) and thereafter housed individually. Henceforth, the body weights were monitored on a weekly basis until 11 months of age.

\section{Organ weights}

The animals were killed by $\mathrm{CO}_{2}$ inhalation. The organ weights of 21-d-old and 11-monthold rats were recorded. These were the pancreas, liver, muscle, spleen, kidney, heart, thymus, lung and brain. A defined sample of muscle was removed, which represented the entire anterior tibialis and soleus muscle from the right hind leg. At $21 \mathrm{~d}$ of age the numbers of rats studied in the control and low protein groups were twenty-three males and twentyfour females from twelve litters in each group; whereas in the postnatal low protein and prenatal low protein groups, twenty-two males and twenty-two females from eleven litters were studied. At 11 months, six males and six females from six litters were studied in each of the groups.

\section{Statistical analysis}

ANOVA, Student's $t$ tests and regression analysis were used. For 21-d-old pups, combined data for males and females are shown since no sex differences were evident at this age. 
However, at the age of 11 months, sex differences justified analysing the data according to sex.

\section{RESULTS}

Reproductive performance in pregnant rats

The total weight gain of pregnant rats on the $80 \mathrm{~g}$ protein $/ \mathrm{kg}$ diet was significantly less than that for pregnant rats on the $200 \mathrm{~g}$ protein $/ \mathrm{kg}$ diet (Table 2). Although the low level of protein in the diet did not affect the litter size, the litter weight was considerably lower. Over the $21 \mathrm{~d}$ of gestation there were no differences in total feed and energy intakes of these animals, indicating that the pregnant rats consuming $80 \mathrm{~g}$ protein $/ \mathrm{kg}$ diet were not energy deprived. Furthermore, as intended, the mean total protein intake was significantly lower $(P<0.001)$ in rats on the $80 \mathrm{~g}$ protein $/ \mathrm{kg}$ diet.

Thus, in spite of the low level of protein in their diet the rats were able to attain a satisfactory weight gain with no adverse effect on the number of pups born alive. However, when the $21 \mathrm{~d}$ gestational period was divided into $7 \mathrm{~d}$ periods in order to see the effects on early and late gestation, significant differences were evident with regard to the weight gain and the feed intake of the pregnant rats fed on the two diets.

\section{Feed intake of pregnant rats}

Although the total feed intakes of rats fed on diets of different protein content were not significantly different, the daily feed intakes during the first and second halves of pregnancy were different (Table 3 ). Initially, the rats consuming $80 \mathrm{~g}$ protein $/ \mathrm{kg}$ diet increased their feed intakes during the first $14 \mathrm{~d}$ of pregnancy compared with the rats given $200 \mathrm{~g}$ protein $/ \mathrm{kg}(P<0.01)$. However, during the last $7 \mathrm{~d}$ of pregnancy, the mean feed intake was identical in both groups of rats.

\section{Weight gain of pregnant rats}

The mean daily body-weight gain of the rats fed on the low-protein diet remained similar to that of rats fed on the $200 \mathrm{~g}$ protein $/ \mathrm{kg}$ diet until day 14 of pregnancy (Table 3). Subsequently, until the end of pregnancy the rats fed on the $80 \mathrm{~g}$ protein $/ \mathrm{kg}$ diet gained significantly less weight than the rats fed on $200 \mathrm{~g}$ protein $/ \mathrm{kg}(P<0.001)$.

\section{Body growth until weaning}

Pups from the low protein group had consistently lower body weights than pups from the control group $(P<0.001)$. In both groups, the pups maintained a steady increase in body weight, although those from the low protein group grew at a rate that resulted in a body weight approximately $50 \%$ less than that observed in the controls (Table 4).

In contrast to the aforementioned groups, the rate of growth of pups in the postnatal low protein group steadily decreased so that, even though the initial body weight (i.e. at day 3 ) was comparable with that of the controls, significant differences were evident at 14 and $21 \mathrm{~d}$ of age between the two groups $(P<0.001)$. The reverse was true for the low protein and postnatal low protein groups, that is, the body weights differed at day $3(P<0.001)$, but not subsequently.

Although pups from prenatal low protein group had higher final body weights than those from the low protein and postnatal low protein groups $(P<0.005)$, they were still significantly lower than those of pups from the control group $(P<0.01)$. Thus, over a period of $21 \mathrm{~d}$, pups from the prenatal low protein group exhibited the greatest percentage weight gain. The controls increased their body weight by $462 \%$, the low protein group by $286 \%$, the postnatal low protein group by $163 \%$ and the prenatal low protein group by $521 \%$. It appears, therefore, that the maternal low-protein diet had a greater impact on the 
Table 2. Reproductive performance of rats fed on diets containing 200 or $80 \mathrm{~g}$ protein $/ \mathrm{kg}$ throughout pregnancy $\dagger$

(Mean values and standard deviations for twenty-four rats)

\begin{tabular}{|c|c|c|c|c|}
\hline & \multicolumn{4}{|c|}{ Diet during pregnancy } \\
\hline & \multicolumn{2}{|c|}{$200 \mathrm{~g}$ protein $/ \mathrm{kg}$} & \multicolumn{2}{|c|}{$80 \mathrm{~g}$ protein $/ \mathrm{kg}$} \\
\hline & Mean & SD & Mean & SD \\
\hline No. of pregnant rats & 24 & & 24 & \\
\hline Total wt gain $(\mathrm{g})$ & 170 & 34 & $141^{* *}$ & 20 \\
\hline Total feed intake $(\mathrm{g})$ & 537 & 75 & 570 & 66 \\
\hline Total energy intake $(\mathrm{kJ})$ & 8259 & 1159 & 8774 & 1021 \\
\hline Total protein intake $(\mathrm{g})$ & 107 & 15 & $46 * * *$ & 5 \\
\hline Litter size & 13 & 4 & 13 & 4 \\
\hline Litter weight (g) & 100 & 30 & $77^{* *}$ & 25 \\
\hline
\end{tabular}

Mean values were significantly different from those for the $200 \mathrm{~g}$ protein $/ \mathrm{kg}$ diet group: ${ }^{* *} P<0 \cdot 01,{ }^{* * *} P<$ 0.001 .

† For details of diets and procedures, see Table 1 and p. 592.

Table 3. The effect of a low-protein diet throughout pregnancy on feed intake and weight gain in pregnant rats $\dagger$

(Mean values and standard deviations for twenty-four rats)

\begin{tabular}{|c|c|c|c|c|}
\hline & \multicolumn{4}{|c|}{ Diet during pregnancy } \\
\hline & \multicolumn{2}{|c|}{$200 \mathrm{~g}$ protein $/ \mathrm{kg}$} & \multicolumn{2}{|c|}{$80 \mathrm{~g}$ protein $/ \mathrm{kg}$} \\
\hline & Mean & SD & Mean & SD \\
\hline \multicolumn{5}{|c|}{ Feed intake (g) } \\
\hline Week 1 & $159 \cdot 6$ & $0 \cdot 7$ & $177 \cdot 8^{* *}$ & 0.7 \\
\hline Week 2 & $183 \cdot 4$ & 0.7 & $203 \cdot 0^{* *}$ & 0.6 \\
\hline Week 3 & $188 \cdot 3$ & $0 \cdot 7$ & $188 \cdot 3$ & 0.6 \\
\hline \multicolumn{5}{|c|}{ Weight gain (g) } \\
\hline Week 1 & $28 \cdot 3$ & $2 \cdot 0$ & $28 \cdot 3$ & $2 \cdot 5$ \\
\hline Week 2 & $45 \cdot 2$ & $1 \cdot 6$ & 47.9 & $2 \cdot 7$ \\
\hline Week 3 & $107 \cdot 2$ & $3 \cdot 9$ & $76 \cdot 4 * * *$ & 2.9 \\
\hline
\end{tabular}

Mean values were significantly different from those for the $200 \mathrm{~g}$ protein $/ \mathrm{kg}$ diet group: ** $P<0 \cdot 01,{ }^{* * *} P<$ 0.001 .

$\dagger$ For details of diets and procedures, see Table 1 and p. 592.

body weights of those rats which were previously growing rapidly (i.e. pups from the postnatal low protein group).

\section{Body growth after weaning}

The male rats had higher body weights than female rats. The deficit in body weight observed in the low protein and the postnatal low protein groups during the pre-weaning period was permanent, despite a normal diet being restored at weaning. At all times their growth curves were parallel but below that of the control rats. Conversely, the prenatal low protein rats showed a rapid 'catch-up' in growth during the postnatal period. Hence at 11 months both the male and female rats in the prenatal low protein group had body weights 
Table 4. Change in body weight $(\mathrm{g})$ over time in offspring of rats fed on diets containing $200 \mathrm{~g}$ protein $/ \mathrm{kg}$ (control) or $80 \mathrm{~g}$ protein $/ \mathrm{kg}$ (low protein) throughout pregnancy and lactation, and offspring cross-fostered with dams fed on these diets (postnatal low protein and prenatal low protein $\dagger$

(Mean values and standard deviations for twelve litters per group, with eight pups (four males, four females) in each litter)

\begin{tabular}{|c|c|c|c|c|c|c|c|c|}
\hline \multirow[t]{2}{*}{ Age (d)... } & \multicolumn{2}{|c|}{3} & \multicolumn{2}{|c|}{7} & \multicolumn{2}{|c|}{14} & \multicolumn{2}{|c|}{21} \\
\hline & Mean & SD & Mean & SD & Mean & SD & Mean & SD \\
\hline Control & $8 \cdot 8$ & 0.4 & $16 \cdot 2$ & $0 \cdot 7$ & $33 \cdot 3$ & $1 \cdot 0$ & $49 \cdot 1$ & $1 \cdot 7$ \\
\hline Low protein & $6 \cdot 4$ & 0.4 & 10.5 & 0.5 & $15 \cdot 9$ & $0 \cdot 8$ & $21 \cdot 3$ & $1 \cdot 3$ \\
\hline Postnatal low protein & $8 \cdot 4$ & $0 \cdot 4$ & $11 \cdot 1$ & $0 \cdot 3$ & $15 \cdot 1$ & 0.5 & $20 \cdot 2$ & $1 \cdot 0$ \\
\hline Prenatal low protein & $6 \cdot 1$ & 0.3 & $12 \cdot 8$ & $1 \cdot 7$ & $29 \cdot 8$ & $1 \cdot 3$ & $44 \cdot 2$ & $1 \cdot 7$ \\
\hline
\end{tabular}

$\uparrow$ For details of diets and procedures, see Table 1 and pp. 592-593.

indistinguishable from those of the controls $(721 \cdot 2$ (SD 61.3) g v. $769 \cdot 0$ (SD 65.4) g for male rats; 456.8 (SD 92.5) g v. 478.1 (SD 41.1) g for female rats respectively). However, the low protein and the postnatal low protein groups at 11 months had significantly lower body weights (643.3 (SD 35.6) $\mathrm{g}$ and 653.6 (SD 56.0) $\mathrm{g}$ for male rats; 402.7 (SD 42.8) $\mathrm{g}$ and 383.8 (SD 50.2) $\mathrm{g}$ for female rats respectively) than the controls $(P<0.01)$.

\section{Organ growth in weanling rats}

Since the total body weight may not reflect the growth of specific organs, weights of individual organs were taken. The organ growth in offspring of protein-restricted mothers could be grouped into three categories:

(1) Greater reduction in organ weights than body weight. This category included the pancreas, spleen, muscle and liver, which were considerably smaller in pups of the low protein and postnatal low protein groups than in the control pups $(P<0.001)$. This was true even when expressed as a percentage of body weight $(P<0.001)$, although the muscle was less markedly smaller $(P<0.01)$ (Tables 5 and 6$)$. Restoring adequate protein after birth, as in the case of the prenatal low protein pups, resulted in complete recovery in the weights of pancreas and spleen with muscle and liver showing only partial recovery compared with the controls $(P<0.05)$.

(2) Reduction in organ weights in proportion to body weight. This included heart, kidney and thymus. Although these organs were lighter in the low protein and postnatal low protein groups when compared with the controls $(P<0.001)$ (Table 5), no differences were evident between the groups when the weights were expressed relative to body weight, except in the case of heart (Table 6). This was significantly lighter in the postnatal low protein group $(P<0.05)$, whereas in the prenatal low protein pups it was heavier $(P<0.05)$.

(3) Less reduction in organ weight than body weight. This included the lung and brain which were relatively protected in the low protein and the postnatal low protein groups. Even though these organs were significantly lighter than in controls (Table 5), when expressed relative to the body weight they were proportionately heavier $(P<0.001)$ (Table 6). The prenatal low protein pups showed no significant difference from the control, indicating full recovery in terms of weight.

Thus, organ weights were affected to a similar degree whether protein was restricted solely during the postnatal period or throughout the prenatal and postnatal periods. The 
Table 5. Organ weights of 21-d-old pups from dams fed on diets containing $200 \mathrm{~g}$ protein $/ \mathrm{kg}$ (control) or $80 \mathrm{~g}$ protein $/ \mathrm{kg}$ (low-protein) throughout pregnancy and lactation, and pups cross-fostered with dams fed on these diets (postnatal low protein and prenatal low protein) $\ddagger$

(Mean values and standard deviations for male and female pups together)

\begin{tabular}{|c|c|c|c|c|c|c|c|c|}
\hline & \multicolumn{2}{|c|}{ Control } & \multicolumn{2}{|c|}{ Low protein } & \multicolumn{2}{|c|}{ Postnatal low protein } & \multicolumn{2}{|c|}{ Prenatal low protein } \\
\hline & Mean & SD & Mean & SD & Mean & SD & Mean & SD \\
\hline$n$ & \multicolumn{2}{|c|}{47} & \multicolumn{2}{|l|}{47} & \multicolumn{2}{|l|}{44} & \multicolumn{2}{|c|}{44} \\
\hline Pancreas (mg) & $212 \cdot 9$ & $56 \cdot 3$ & $71 \cdot 1 * * * \dagger+\dagger$ & $24 \cdot 7$ & $65 \cdot 4 * * *+\dagger \dagger$ & $18 \cdot 8$ & $170 \cdot 8$ & $42 \cdot 1$ \\
\hline Muscle (mg) & $142 \cdot 0$ & 26.0 & $48 \cdot 0 * * *+\dagger \dagger$ & $12 \cdot 0$ & $58 \cdot 5 * * *+\dagger \dagger$ & $11 \cdot 0$ & $98 \cdot 7^{*}$ & $19 \cdot 0$ \\
\hline Liver (g) & 1.97 & 0.48 & $0.73 * * *++1$ & 0.19 & $0.71 * * *+1 \dagger$ & 0.14 & $1.67^{*}$ & 0.32 \\
\hline Spleen (mg) & 198.4 & $66 \cdot 3$ & $59 \cdot 9 * * *+1 \dagger$ & $20 \cdot 6$ & $53 \cdot 3^{* * *}+1+$ & $14 \cdot 5$ & $186 \cdot 5$ & $54 \cdot 0$ \\
\hline Heart (mg) & $403 \cdot 1$ & 67.8 & $162 \cdot 7^{* * *+\dagger \dagger}$ & $44 \cdot 2$ & $135 \cdot 4^{* * *}+\dagger \dagger$ & 28.9 & $423 \cdot 7$ & $99 \cdot 8$ \\
\hline Kidney (mg) & 620.0 & $72 \cdot 3$ & $265 \cdot 5^{* * * *+\dagger \dagger}$ & 60.9 & $261 \cdot 7 * * *+\dagger \dagger$ & 440 & 527.2 & $77 \cdot 4$ \\
\hline Thymus (mg) & 192.4 & 83.6 & $81 \cdot 2 * * *++\dagger$ & 26.7 & $83 \cdot 0 * * *+\dagger \dagger$ & $29 \cdot 3$ & 173.8 & $65 \cdot 3$ \\
\hline Lung (mg) & 527.8 & $99 \cdot 1$ & $283 \cdot 3 * * *+\dagger \dagger$ & $48 \cdot 1$ & $293 \cdot 7 * * *++\dagger$ & $47 \cdot 1$ & 539.4 & $77 \cdot 2$ \\
\hline Brain (g) & 1.48 & 0.08 & $1 \cdot 29 * \dagger$ & 0.07 & $1 \cdot 26^{* \dagger} \dagger$ & 0.06 & 1.42 & 0.09 \\
\hline
\end{tabular}

Mean values were significantly different from those for the control group: $* P<0.05, * * * P<0.001$.

Mean values were significantly different from those for the prenatal low protein group: $\dagger P<0.05, \dagger \dagger \uparrow P<$ 0.001 .

$\$$ For details of diets and procedures, see Table 1 and pp. 592-593.

Table 6. Organ weights relative to body weights $(\%)$ of 21 -d-old pups from dams fed on diets containing $200 \mathrm{~g}$ protein $/ \mathrm{kg}$ (control) or $80 \mathrm{~g}$ protein $/ \mathrm{kg}$ (low-protein) throughout pregnancy and lactation and pups cross-fostered with dams fed on these diets (postnatal low protein and prenatal low protein) $\ddagger$

(Mean values and standard deviations for male and female pups together)

\begin{tabular}{|c|c|c|c|c|c|c|c|c|}
\hline & \multicolumn{2}{|c|}{ Control } & \multicolumn{2}{|c|}{ Low protein } & \multicolumn{2}{|c|}{ Postnatal low protein } & \multicolumn{2}{|c|}{ Prenatal low protein } \\
\hline & Mean & SD & Mean & $\mathrm{SD}$ & Mean & SD & Mean & SD \\
\hline$n$ & \multicolumn{2}{|c|}{47} & \multicolumn{2}{|l|}{47} & \multicolumn{2}{|c|}{44} & \multicolumn{2}{|c|}{44} \\
\hline Pancreas & 0.45 & $0-05$ & $0.33 * * *+\dagger$ & $0-06$ & $0 \cdot 32 * * *+\dagger$ & 0.05 & 0.39 & 0.05 \\
\hline Muscle & $0 \cdot 24$ & 0.03 & $0 \cdot 19^{* *}$ & 0.03 & $0.21 *$ & 0.02 & $0 \cdot 21^{*}$ & 0.02 \\
\hline Liver & $4 \cdot 1$ & $0 \cdot 28$ & $3 \cdot 5 * * *$ & 0.30 & $3 \cdot 5^{* * *}$ & $0 \cdot 25$ & $3.8^{*}$ & 0.26 \\
\hline Spleen & 0.40 & 0.08 & $0.29 * * *+\dagger \dagger$ & 0.06 & $0 \cdot 26 * * *+\dagger \dagger$ & 0.03 & $0 \cdot 43$ & 0.26 \\
\hline Heart & 0.83 & $0 \cdot 16$ & $0 \cdot 79$ & $0 \cdot 15$ & $0.67 *+1+$ & $0-07$ & $0.99^{*}$ & 0.23 \\
\hline Kidney & $1 \cdot 3$ & 0.09 & $1 \cdot 3$ & $0 \cdot 10$ & $1 \cdot 3$ & $0 \cdot 12$ & $1 \cdot 2$ & $0 \cdot 11$ \\
\hline Thymus & 0.38 & 0.09 & 0.39 & 0.07 & 0.41 & 0.09 & $0 \cdot 39$ & 0.09 \\
\hline Lung & $1 \cdot 1$ & 0.17 & $1 \cdot 4^{* * *}$ & 0.14 & $1 \cdot 5^{* * *}$ & $0 \cdot 16$ & $1 \cdot 3$ & 0.18 \\
\hline Brain & $3 \cdot 2$ & 0.49 & $6 \cdot 4^{* * *}+1+$ & 0.90 & $6 \cdot 4 * * *+1 \dagger$ & 0.83 & $3 \cdot 4$ & 0.38 \\
\hline
\end{tabular}

Mean values were significantly different from those for the control group: ${ }^{*} P<0.05,{ }^{* *} P<0 \cdot 01,{ }^{* * *} P<$ 0.001 .

Mean values were significantly different from those for the prenatal low protein group: $\dagger \dagger P<0.01,+\dagger+P<$ $0 \cdot 001$.

$\ddagger$ For details of diets and procedures, see Table 1 and pp. 592-593. 
Table 7. Organ weights of 11-month-old male offspring from dams fed on diets containing $200 \mathrm{~g}$ protein $/ \mathrm{kg}$ (control) or $80 \mathrm{~g}$ protein $/ \mathrm{kg}$ (low-protein) throughout pregnancy and lactation, and offspring cross-fostered with dams fed on these diets (postnatal low-protein and prenatal low protein $) \dagger$

(Mean values and standard deviations for six animals)

\begin{tabular}{|c|c|c|c|c|c|c|c|c|}
\hline & \multicolumn{2}{|c|}{ Control } & \multicolumn{2}{|c|}{ Low protein } & \multicolumn{2}{|c|}{ Postnatal low protein } & \multicolumn{2}{|c|}{ Prenatal low protein } \\
\hline & Mean & SD & Mean & SD & Mean & SD & Mean & SD \\
\hline Body weight (g) & $769 \cdot 0$ & $65 \cdot 4$ & $643 \cdot 3$ & $35 \cdot 6$ & $653 \cdot 6$ & $65 \cdot 6$ & $721 \cdot 2$ & $61 \cdot 3$ \\
\hline Pancreas (g) & $1 \cdot 39$ & $0 \cdot 10$ & $1 \cdot 31$ & $0 \cdot 12$ & $1 \cdot 61$ & $0 \cdot 26$ & 1.47 & $0 \cdot 11$ \\
\hline Muscle (g) & $1 \cdot 51$ & $0 \cdot 25$ & $1 \cdot 18^{* *}$ & 0.17 & $0.96^{* *}$ & $0 \cdot 22$ & $1 \cdot 03 * *$ & $0 \cdot 32$ \\
\hline Liver $(\mathrm{g})$ & $33 \cdot 5$ & $3 \cdot 1$ & $30 \cdot 0$ & $5 \cdot 4$ & $26 \cdot 8$ & $6-2$ & $32 \cdot 5$ & $5 \cdot 1$ \\
\hline Spleen (g) & $1 \cdot 26$ & $0 \cdot 28$ & $1 \cdot 19$ & $0 \cdot 10$ & 0.99 & $0 \cdot 26$ & $1 \cdot 34$ & $0 \cdot 25$ \\
\hline Heart $(\mathrm{g})$ & $2 \cdot 02$ & $0 \cdot 20$ & 1.82 & $1 \cdot 30$ & 1.69 & 0.24 & 1.94 & 0.47 \\
\hline Kidney (g) & 6.00 & $0 \cdot 70$ & $5 \cdot 21$ & $1 \cdot 20$ & $4 \cdot 60$ & $0 \cdot 90$ & $6 \cdot 42$ & $1 \cdot 40$ \\
\hline Thymus (mg) & $1 \cdot 24$ & $0 \cdot 17$ & 1.05 & 0.25 & $1 \cdot 18$ & 0.28 & $1 \cdot 24$ & $0 \cdot 41$ \\
\hline Lung (g) & $2 \cdot 41$ & $0 \cdot 21$ & $2 \cdot 11$ & $0 \cdot 12$ & $2 \cdot 21$ & $0 \cdot 14$ & $2 \cdot 17$ & $0 \cdot 22$ \\
\hline Brain (g) & $2 \cdot 16$ & $0 \cdot 11$ & $2 \cdot 23$ & 0.06 & $2 \cdot 07$ & $0 \cdot 04$ & $2 \cdot 14$ & 0.11 \\
\hline
\end{tabular}

Mean values were significantly different from that for the control group: ${ }^{* *} P<0.01$.

$\dagger$ For details of diets and procedures, see Table 1 and pp. 592-593.

Table 8 . Organ weights relative to body weights (\%) in 11-month-old male offspring from dams fed on diets containing $200 \mathrm{~g}$ protein $/ \mathrm{kg}$ (control) or $80 \mathrm{~g}$ protein $/ \mathrm{kg}$ (low protein) throughout pregnancy and lactation, and offspring cross-fostered with dams fed on these diets (postnatal low protein and prenatal low protein) $\dagger$

(Mean values and standard deviations for six animals)

\begin{tabular}{|c|c|c|c|c|c|c|c|c|}
\hline & \multicolumn{2}{|c|}{ Control } & \multicolumn{2}{|c|}{ Low protein } & \multicolumn{2}{|c|}{ Postnatal low protein } & \multicolumn{2}{|c|}{ Prenatal low protein } \\
\hline & Mean & SD & Mean & SD & Mean & SD & Mean & $\mathrm{SD}$ \\
\hline Pancreas & $0 \cdot 18$ & 0.01 & $0 \cdot 20$ & 0.02 & $0 \cdot 18$ & 0.02 & 0.21 & 0.05 \\
\hline Muscle & $0 \cdot 27$ & 0.03 & $0 \cdot 18 * * *$ & 0.20 & $0 \cdot 15^{* * *}$ & 0.02 & $0 \cdot 15^{* * *}$ & $0 \cdot 40$ \\
\hline Liver & $4 \cdot 40$ & $0 \cdot 30$ & $4 \cdot 70$ & 0.60 & $4 \cdot 10$ & 0.50 & $4 \cdot 60$ & 0.50 \\
\hline Spleen & $0 \cdot 16$ & 0.03 & 0.19 & 0.01 & $0 \cdot 16$ & 0.02 & 0.19 & 0.05 \\
\hline Heart & 0.27 & 0.03 & 0.28 & $0 \cdot 20$ & 0.26 & 0.02 & 0.29 & $0 \cdot 14$ \\
\hline Kidney & 0.78 & 0.09 & 0.81 & $0 \cdot 15$ & 0.70 & 0.08 & 0.90 & $0 \cdot 17$ \\
\hline Thymus & $0 \cdot 16$ & $0-01$ & $0 \cdot 17$ & 0.02 & $0 \cdot 18$ & $0 \cdot 14$ & $0 \cdot 17$ & 0.03 \\
\hline Lung & $0 \cdot 32$ & 0.05 & 0.33 & 0.02 & 0.34 & 0.07 & $0 \cdot 31$ & $0 \cdot 05$ \\
\hline Brain & $0 \cdot 28$ & 0.03 & $0 \cdot 34^{* *}$ & 0.02 & 0.32 & 0.06 & $0 \cdot 31$ & 0.07 \\
\hline
\end{tabular}

Mean values were significantly different from those for the control group: ${ }^{* *} P<0.01,{ }^{* * *} P<0 \cdot 001$.

$\dagger$ For details of diets and procedures, see Table 1 and pp. 592-593.

ability to recuperate in terms of growth was demonstrated by organs such as the pancreas, spleen, lung and brain. Interestingly, the liver and muscle showed only partial recovery at weaning, suggesting that the period of rehabilitation may not have been sufficient.

\section{Organ growth after weaning}

At 11 months of age, significant differences in organ growth were evident only with regard to pancreas, muscle and brain. Moreover, the adult male and female rats showed a differential response as a result of maternal low-protein diet. In the case of the male rats 
Table 9. Organ weights of 11-month-old female offspring from dams fed on diets containing $200 \mathrm{~g}$ protein $/ \mathrm{kg}$ (control) or $80 \mathrm{~g}$ protein $/ \mathrm{kg}$ (low protein) throughout pregnancy and lactation, and offspring cross-fostered with dams fed on these diets (postnatal low protein and prenatal low protein $) \dagger$

(Mean values and standard deviations for six animals)

\begin{tabular}{|c|c|c|c|c|c|c|c|c|}
\hline & \multicolumn{2}{|c|}{ Control } & \multicolumn{2}{|c|}{ Low protein } & \multicolumn{2}{|c|}{ Postnatal low protein } & \multicolumn{2}{|c|}{ Prenatal low protein } \\
\hline & Mean & $\mathrm{SD}$ & Mean & SD & Mean & SD & Mean & SD \\
\hline Body weight (g) & $478 \cdot 1$ & $41 \cdot 1$ & $402 \cdot 7$ & $42 \cdot 8$ & 383.8 & $50 \cdot 2$ & 456.8 & $92 \cdot 5$ \\
\hline Pancreas (g) & 1.01 & $0 \cdot 20$ & 1.00 & 0.22 & 0.99 & $0 \cdot 24$ & 1.06 & $0 \cdot 25$ \\
\hline Muscle (g) & 0.80 & 0.11 & 0.61 & 0.18 & $0.61^{* *}$ & 0.07 & $0.64 *$ & 0.08 \\
\hline Liver $(\mathrm{g})$ & $19 \cdot 4$ & $4 \cdot 4$ & $16 \cdot 8$ & $2 \cdot 9$ & $16 \cdot 5$ & $2 \cdot 4$ & $20 \cdot 2$ & $5 \cdot 6$ \\
\hline Spleen $(\mathrm{g})$ & 0.86 & $0 \cdot 18$ & 0.77 & 0.13 & $0.62 * *$ & $0 \cdot 11$ & 0.75 & 0.09 \\
\hline Heart (g) & $1 \cdot 50$ & $0 \cdot 11$ & $1 \cdot 28$ & $0 \cdot 11$ & 1.25 & $0 \cdot 16$ & $1 \cdot 38$ & 0.18 \\
\hline Kidney (g) & $3 \cdot 80$ & 0.60 & $3 \cdot 10$ & $0 \cdot 70$ & 3.00 & 0.70 & 3.80 & 0.90 \\
\hline Thymus (mg) & $1 \cdot 12$ & 0.19 & 0.95 & 0.23 & 0.86 & $0 \cdot 13$ & $1 \cdot 15$ & $0 \cdot 33$ \\
\hline Lung (g) & 1.90 & 0.27 & 1.66 & 0.23 & 1.66 & 0.20 & $1 \cdot 73$ & 0.08 \\
\hline Brain (g) & 1.91 & 0.17 & 1.93 & $0 \cdot 14$ & 1.92 & $0 \cdot 11$ & 1.94 & 0.09 \\
\hline
\end{tabular}

Mean values were significantly different from those for the control group: ${ }^{*} P<0.05, * * P<0 \cdot 01$.

+ For details of diets and procedures, see Table 1 and pp. 592-593.

Table 10. Organ weights relative to body weights $(\%)$ of 11-month-old female offspring from dams fed on diets containing $200 \mathrm{~g}$ protein $/ \mathrm{kg}$ (control) or $80 \mathrm{~g}$ protein $/ \mathrm{kg}$ (low-protein) throughout pregnancy and lactation, and offspring cross-fostered with dams fed on these diets (postnatal low protein and prenatal low protein) $\dagger$

(Mean values and standard deviations for six animals)

\begin{tabular}{|c|c|c|c|c|c|c|c|c|}
\hline & \multicolumn{2}{|c|}{ Control } & \multicolumn{2}{|c|}{ Low protein } & \multicolumn{2}{|c|}{ Postnatal low protein } & \multicolumn{2}{|c|}{ Prenatal low protein } \\
\hline & Mean & SD & Mean & SD & Mean & SD & Mean & SD \\
\hline Pancreas & $0 \cdot 20$ & 0.03 & $0 \cdot 25^{*}$ & 0.03 & $0 \cdot 26^{* *}$ & 0.02 & 0.23 & 0.04 \\
\hline Muscle & $0 \cdot 16$ & $0-02$ & $0 \cdot 17$ & 0.04 & $0 \cdot 16$ & 0.03 & $0 \cdot 15^{* * *}$ & $0 \cdot 40$ \\
\hline Liver & 3.90 & 0.40 & $4 \cdot 20$ & 0.40 & $4 \cdot 20$ & $0 \cdot 30$ & $4 \cdot 40$ & 0.50 \\
\hline Spleen & $0 \cdot 18$ & 0.02 & 0.19 & 0.03 & $0 \cdot 16$ & 0.02 & $0 \cdot 17$ & 0.03 \\
\hline Heart & $0 \cdot 30$ & 0.01 & 0.32 & 0.02 & $0 \cdot 33$ & 0.03 & $0 \cdot 30$ & 0.03 \\
\hline Kidney & 0.81 & $0-08$ & 0.77 & $0 \cdot 10$ & $0 \cdot 78$ & $0 \cdot 11$ & 0.82 & $0 \cdot 16$ \\
\hline Thymus & 0.23 & $0 \cdot 04$ & 0.24 & 0.06 & 0.22 & $0 \cdot 04$ & 0.25 & 0.05 \\
\hline Lung & 0.39 & 0.06 & 0.42 & 0.05 & 0.44 & 0.06 & 0.39 & 0.05 \\
\hline Brain & 0.38 & 0.05 & $0 \cdot 49^{* *}$ & 0.05 & $0.51^{* *}$ & $0-06$ & 0.44 & 0.07 \\
\hline
\end{tabular}

Mean values were significantly different from those for the control group: ${ }^{*} P<0.05, * * P<0.01, * * * P<$ 0.001 .

$\dagger$ For details of diets and procedures, see Table 1 and pp. 592-593.

the relative weight of the muscle was significantly lower $(P<0.001)$ in the three experimental groups than in the control rats, whereas the relative weight of the brain was still higher $(P<0.01)$ only in the low protein rats. However, the absolute and the relative weights of pancreas and liver were similar in the four groups (Tables 7 and 8). Conversely, the female rats from the low protein and the postnatal low protein groups had greater relative weights of pancreas $(P<0.05 ; P<0.01$ respectively) and brain $(P<0.01)$, with the prenatal low protein rats showing no such differences. Although the weight of the muscle 
was significantly lower in the postnatal low protein $(P<0.01)$ and the prenatal low protein rats $(P<0.05)$, the relative weight of muscle was not different from the control group. Once again, the liver showed complete recovery in growth (Tables 9 and 10).

Thus, maternal protein deprivation caused sex-dependent selective and permanent organ and body-weight changes in the offspring. In the male rats the growth of muscle was permanently affected, whereas in the case of the female rats it was the pancreas. In both sexes the brain was relatively heavy.

\section{DISCUSSION}

We have investigated the impact of maternal protein deficiency during gestation and/or lactation on the development of the fetus or sucking animal. It is, however, possible that the availability of a wide variety of nutrients to the fetus and sucking pup could be affected, for example, the placental growth and function or the process of lactation. Previous studies have shown that in protein-deficient guinea-pigs (Young \& Widdowson, 1975) and rats (Ross, 1975) there is altered placental transfer of nutrients to the fetus. Also, the amount of protein consumed by the pregnant and lactating rat affects lactation (Sampson et al. 1986).

In the present study there was an increase in feed intake in the protein-restricted group during the first $14 \mathrm{~d}$ of pregnancy. It has been postulated that on marginally deficient diets feed intake might be stimulated in order to increase the availability of a limiting nutrient (Widdowson \& McCance, 1975). Although, in the present study, the increase in feed intake would inevitably have resulted in an increase in protein intake, it was not sufficient to offset the effect of the low-protein diet, or the total amount of protein consumed, which was significantly lower in rats fed on the $80 \mathrm{~g}$ protein $/ \mathrm{kg}$ diet than in rats fed on the $200 \mathrm{~g}$ protein $/ \mathrm{kg}$ diet.

The daily body-weight gain of pregnant rats was affected by the low-protein diet only during the last $7 \mathrm{~d}$ of gestation. All the same, the reduction in weight gain during this period was sufficient to cause an overall reduction in the total weight gain of pregnant rats fed on the $80 \mathrm{~g}$ protein $/ \mathrm{kg}$ diet compared with pregnant rats fed on the $200 \mathrm{~g}$ protein $/ \mathrm{kg}$ diet. It is noteworthy in this respect that an increase in feed intake was coincident with the period in which the rats fed on the low-protein diet were able to attain a similar weight gain as the rats fed on the $200 \mathrm{~g}$ protein $/ \mathrm{kg}$ diet. However, despite this similar weight gain, and although there was partial compensation for protein intake by rats fed on the $80 \mathrm{~g}$ protein $/ \mathrm{kg}$ diet as a result of increased feed intake, it cannot be assumed that the fetus is not affected at this stage by lack of protein in the maternal diet. The litter size was not adversely affected by the level of protein in the diet. Similar observations have been made by Wunderlich et al. (1979) with a diet containing $50 \mathrm{~g}$ protein $/ \mathrm{kg}$, and Snoeck et al. (1990) with a diet containing $80 \mathrm{~g}$ protein $/ \mathrm{kg}$.

The lower body weight of the pups of mothers fed on a low-protein diet became apparent at birth. The offspring had approximately $35 \%$ lower body weight than offspring of mothers fed on an adequate-protein diet. Postnatal nutrition appeared to play a major role in determining subsequent growth. This was reflected by the fact that the postnatal growth either faltered or accelerated irrespective of the body weight at day 3 . Thus, if pups in their fetal life were subjected to adequate maternal protein, and thereafter were nursed by a mother fed on a protein-restricted diet (postnatal low protein group), postnatal growth retardation was evident. On the other hand, if pups had a lower body weight at $3 \mathrm{~d}$ of age as a result of low maternal protein during gestation, but were then nursed by a mother fed on a $200 \mathrm{~g}$ protein $/ \mathrm{kg}$ diet (prenatal low protein group), they demonstrated an acceleration in growth rate, after an initial lag phase. However, at weaning (21 d) their weight still remained well below that of the control pups. 
The time during which nutritional rehabilitation occurred was equally important. Return to optimal diet at weaning ( $21 \mathrm{~d}$ of age) did not correct the body deficits. This was true whether the offspring had been subjected to maternal protein restriction either solely during the postnatal period (postnatal low protein) or during the combined period of prenatal and postnatal life (low protein). In fact, both groups showed very similar growth patterns. On the other hand, if the offspring were rehabilitated during the preweaning period, that is, just after birth, no such lasting deficits in body weight were seen. This was in spite of prenatal exposure to maternal low-protein diet (prenatal low protein). From these observations it emerges that the postnatal period rather than the prenatal period is critical for overall growth.

The maternal protein deprivation affected not only the overall growth in the offspring, but also caused a change in body composition such that organs were selectively affected. Although the lower weight of some of the organs was proportional to the lower body weight, other organs such as the brain and lung were proportionally less affected. By contrast, pancreas, liver, muscle and spleen weights each tended to be proportionally lower than the body weight. The phenomenon of 'brain sparing' has previously been observed in animals (Widdowson \& McCance, 1960; Winick \& Noble, 1966), small-for-gestationalage babies (Gruenwald, 1963; Ogata et al. 1985) and in malnourished children (Garrow $e t$ al. 1965; Winick et al. 1970), and may result from an apparent redistribution of blood flow that increases blood flow to the brain (Cahill, 1970; Simmons et al. 1992). Despite this relative preservation of the brain, studies on functional aspects of the brain have shown that the progeny of protein-restricted mothers have a series of behavioural changes and learning incompetence when they become adults (Rider \& Simonson, 1974; Smart, 1993).

Furthermore, recovery in organ weight in later life may not necessarily reflect recovery in structure and function. For instance in the present study, although the liver weights were indistinguishable in the four groups, in a previous study the hepatic metabolism was profoundly affected as a result of maternal protein restriction during pregnancy (Desai $e t$ al. 1994, 1995). Also, previous studies have shown that prenatal growth retardation due to maternal malnutrition causes a permanent abnormality of the structure and functional capacity of the kidneys (Allen \& Zeman, 1973; Hinchcliffe et al. 1992). The recovery in the weight of pancreas observed in the adult male rats, and particularly the relative increase in the female rats, may be attributable to the more rapid growth of the exocrine region of the pancreas during the postnatal rather than the prenatal life.

The sex-dependent selective and permanent change in organ weights in older rats is difficult to explain, but may result from the comparatively rapid growth trajectory of males, which would render them more vulnerable to early maternal protein restriction. In particular, the lower muscle weight relative to the body weight persists in adult life in the male rats but not in the female rats. It is known that the muscle is in large part responsible for the metabolic disposal of a glucose challenge and is an important site of insulin resistance (DeFronzo, 1988). Furthermore, studies on early nutrition and adult onset of diseases have shown that not only is the low ponderal index at birth associated with insulin resistance syndrome particularly in men (Phillips et al. 1994), but such babies have evidence of reduced muscle and subcutaneous tissue (Robinson et al. 1991). Similarly, several animal studies suggest that early malnutrition imposed during fetal or early postnatal life results in reduced muscle mass which is not reversed by later refeeding (Winick \& Noble, 1966; Widdowson, 1971; Fleagle et al. 1975). Other studies have further shown that besides the deficits in muscle weight there are lasting alterations in the relative proportions of muscle fibre types, fibre number and fibre size (Haltia et al. 1978; Howells \& Jordon, 1978; Bedi et al. 1982). The functional consequences of these muscular differences on glucose and insulin metabolism are not yet known. 
Thus, the present study shows that the neonate, when exposed to maternal low-protein diet during the critical period of development, is capable of compromising by reprogramming its potential for development. This reprogramming appears to be permanent, implying that the true potential of the growth-retarded neonate can never be realized. In particular this study demonstrates the immediate effects on general and organ growth following maternal protein restriction and the subsequent recovery, if any, after nutritional rehabilitation over a lengthy period. The ranking of relative organ growth further reveals the organs which are most vulnerable to maternal low-protein diet.

We thank D. Hutt, A. Flack, A. Wayman and L. Smith of Dunn Nutritional Laboratory, Animal Unit, for their invaluable assistance. This work was supported by the British Diabetic Association and the Medical Research Council.

\section{REFERENCES}

Allen, L. H. \& Zeman, F. J. (1973). Kidney function in the progeny of protein-deficient rats. Journal of Nutrition $103,1467-1478$.

Barker, D. J. P., Bull, A. R., Osmond, C. \& Simmonds, S. J. (1990). Fetal and placental size and risk of hypertension in adult life. British Medical Journal 301, 259-262.

Barker, D. J. P., Hales, C. N., Fall, C. H. D., Osmond, C., Phipps, K. \& Clark, P. M. S. (1993). Type 2 (noninsulin-dependent) diabetes mellitus, hypertension and hyperlipidaemia (syndrome X): relation to reduced fetal growth. Diabetologia 36, 62-67.

Barker, D. J. P., Meade, T. W., Fall, C. H. D., Lee, A., Osmond, C., Phipps, K. \& Stirling, Y. (1992). Relation of fetal and infant growth to plasma fibrinogen and factor VII concentrations in adult life. British Medical Journal 304, 148-152.

Bedi, K. S., Birzgalis, A. R., Mahon, M., Smart, J. L. \& Wareham, A. C. (1982). Early life undernutrition in rats. British Journal of Nutrition 47, 417-430.

Cahill, G. F. (1970). Starvation in man. New England Journal of Medicine 282, 668-675.

DeFronzo, R. A. (1988). The triumvirate: beta cell, muscle, liver. A collusion responsible for NIDDM. Diabetes 37, 667-687.

Desai, M., Crowther, N., Lucas, A. \& Hales, C. N. (1994). Programming of hepatic metabolism by early protein restriction. Diabetalogia 37, Suppl. 1, A71, Abstr.

Desai, M., Crowther, N. J., Ozanne, S. E., Lucas, A. \& Hales, C. N. (1995). Adult glucose and lipid metabolism may be programmed during fetal life. Biochemical Society Transactions 23, 329-333.

Fleagle, J. G., Samonds, K. W. \& Hegsted, D. M. (1975). Physical growth of cebus monkeys, cebus albifrons, during protein or calorie deficiency. American Journal of Clinical Nutrition 28, 246-253.

Garrow, J. S., Fletcher, K. \& Halliday, D. (1965). Body composition in severe infantile malnutrition. Journal of Clinical Investigation 44, 417-425.

Gruenwald, P. (1963). Chronic fetal distress and placental insufficiency. Biology of the Neonate 5, $215-219$.

Hales, C. N. \& Barker, D. J. P. (1992). Type 2 (non-insulin-dependent) diabetes mellitus: the thrifty phenotype hypothesis. Diabetologia 35, 595-601.

Hales, C. N., Barker, D. J. P., Clark, P. M. S., Cox, L. J., Fall, C., Osmond, C. \& Winter, P. D. (1991). Fetal and infant growth and impaired glucose tolerance at age 64 years. British Medical Journal 303, $1019-1022$.

Haltia, M., Berlin, Ö., Schucht, H. \& Sourander, P. (1978). Postnatal differentiation and growth of skeletal muscle fibres in normal and undernourished rats. Journal of Neurology Sciences 36, 25-39.

Hinchcliffe, S. A., Lynch, M. R. J., Sargent, P. H., Howard, C. V. \& Van Velzen, D. (1992). The effect of intrauterine growth retardation on the development of renal nephrons. British Journal of Obstetrics and Gynaecology 99, 296-301.

Howells, K.F. \& Jordon, T. C. (1978). The effects of pre- and perinatal undernutrition on the succinic dehydrogenase content of muscle fibres from fast and slow rat muscles. Histochemistry 58, 97-102.

James, W. P. T. \& Coore, H. G. (1970). Persistent impairment of insulin secretion and glucose tolerance after malnutrition. American Journal of Clinical Nutrition 23, 386-389.

McCance, R. A. \& Widdowson, E. M. (1966). Protein deficiencies and calorie deficiencies. Lancet ii, $158-159$.

McCance, R. A. \& Widdowson, E. M. (1974). The determinants of growth and form. Proceedings of the Royal Society of London 185, 1-17.

Milner, R. D. G. (1971). Metabolic and hormonal responses to glucose and glucagon in patients with infantile malnutrition. Pediatric Research 5, 33-39.

Ogata, E. S., Bussey, M., LaBarbera, A. \& Finley, S. (1985). Altered growth, hypoglycemia, hypoalaninemia, and ketonemia in the young rat: postnatal consequences of intrauterine growth retardation. Pediatric Research 19. $32-37$. 
Phillips, D. I. W., Barker, D. J. P., Hales, C. N., Hirst, S. \& Osmond, C. (1994). Thinness at birth and insulin resistance in adult life. Diabetologia 37, 150-154.

Pimstone, B. L. (1976). Endocrine function in protein-calorie malnutrition. Clinical Endocrinology 5, 79-95.

Rider, A. A. \& Simonson, M. (1974). The relationship between maternal diet, birthweight and behaviour of the offspring in the rat. Nutrition Reports International 10, 19-22.

Robinson, S. M., Wheeler, T., Hayes, M. C., Barker, D. J. P. \& Osmond, C. (1991). Fetal heart rate and intrauterine growth. British Journal of Obstetrics and Gynaecology 98, 1223-1227.

Ross, P. (1975). Maternal malnutrition and placental transfer of $\alpha$-aminoisobutyric acid in the rat. Science 187, $648-649$.

Sampson, D. A., Hunsaker, H. A. \& Jansen, G. R. (1986). Dietary protein quality, protein quantity and food intake: effects on lactation and on protein synthesis and tissue composition in mammary tissue and liver in rats. Journal of Nutrition 116, 365-375.

Simmons, R. A., Gounis, A. S., Bangalore, S. A. \& Ogata, E. S. (1992). Intrauterine growth retardation: fetal glucose transport is diminished in lung but spared in brain. Pediatric Research 31, 59-63.

Smart, J. L. (1993). Behavioural consequences of undernutrition. Proceedings of the Nutrition Society 52, $189-199$.

Snoeck, A., Remacle, C., Reusens, B. \& Hoet, J. J. (1990). Effect of a low protein diet during pregnancy on the fetal rat endocrine pancreas. Biology of the Neonate 57, 107-118.

Stewart, R. J. C., Preece, R. F. \& Sheppard, H. G. (1975). Twelve generations of marginal protein deficiency. British Journal of Nutrition 33, 233-252.

Swenne, I., Crace, C. J. \& Milner, R. D. G. (1987). Persistent impairment of insulin secretory response to glucose in adult rats after limited periods of protein-calorie malnutrition in early life. Diabetes 36, 454-458.

Weinkove, C., Weinkove, E. A. \& Pimstone, B. L. (1974). Insulin release and pancreatic islet volume in malnourished rats. South African Medical Journal 48, 1888.

Widdowson, E. M. (1971). Intra-uterine growth retardation in the pig. 1. Organ size and cellular development at birth and after growth to maturity. Biology of the Neonate 19, 329-340.

Widdowson, E. M. \& McCance, R. A. (1960). Some effects of accelerating growth. 1. General somatic development. Proceedings of the Royal Society London 152, 188-206.

Widdowson, E. M. \& McCance, R. A. (1975). A Review: new thoughts on growth. Pediatric Research 9, $154-156$.

Winick, M. (1971). Cellular changes during placental and fetal growth. American Journal of Obstetrics and Gynecology 109, 166-176.

Winick, M. \& Noble, A. (1966). Cellular response in rats during malnutrition at various ages. Journal of Nutrition 89, 300-306.

Winick, M., Rosso, P. \& Waterlow, J. C. (1970). Cellular growth of cerebrum, cerebellum and brain stem in normal and marasmic children. Experimental Neurology 26, 393-400.

Wunderlich, S. M., Baliga, B. S. \& Munro, H. N. (1979). Rat placental protein synthesis and peptide hormone secretion in relation to malnutrition from protein deficiency and alcohol administration. Journal of Nutrition 109, 1534-1541.

Young, M. \& Widdowson, E. M. (1975). The influence of diets deficient in energy, or in protein, on conceptus weight, and the placental transfer of a non-metabolisable amino acid in the guinea pig. Biology of the Neonate 27, 184-191. 